\title{
A Review on the Novel Coronavirus pandemic (COVID-19) in Bangladesh; Challenges and Initiatives.
}

\author{
Md. Riajul Islam Sardar ${ }^{1}$, Md. Shamim Hasan ${ }^{1}$ and Md. Mahmud ${ }^{1 *}$ \\ ${ }^{1}$ Department of Applied Chemistry and Chemical Engineering, Bangabandhu Sheikh Mujibur \\ Rahman Science \& Technology University, Gopalganj-8100, Bangladesh. \\ *Corresponding Author(Email: hasan.mahmud.edu@gmail.com), Tel: +8801773- \\ 436385
}

\begin{abstract}
Since the first coronavirus patient was identified in Bangladesh on March 8, the most controversial issue is about the exact level of the infection in Bangladesh. Conformly with the population density the number of COVID-19 tests is inadequate. As the number of tests increases, so does the number of infections, making it difficult to predict the spread of COVID-19 in Bangladesh. In this case, the unplanned initiatives are particularly responsible in other for unplanned measures, lack of public awareness, and lack of proper knowledge. In this case, the Ministry of Health has made three major mistakes, three important features of the medical system in Bangladesh have been mentioned. It is more effective to prevent COVID-19 by isolating the infected person by further testing COVID-19 until effective treatment is available and to provide adequate and effective masks and personal protective equipment (PPE). In this case, the COVID-19 testing kit invention has received a good response in many countries of the world. This study focuses on the comprehensive data verification, selection, and evaluation of COVID-19 in Bangladesh and its implications for the future, what to do to address and prevent the COVID-19 challenge, and effective treatment against the coronavirus (COVID-19). It is hopeful that the discussion of the material mentioned in this research paper will help to strike a balance between the government, citizens, and experts which will be feasible in improving the current situation in COVID-19 Bangladesh and reducing its severity.
\end{abstract}

Keywords: COVID-19, Bangladesh, Challenges, Initiatives, Controversial issue

\section{Introduction}

Respiratory distress infections were registered first to the WHO office on 31 December, 2020 in Wuhan, Hubei Province, China, which later spread to China as an epidemic (1).On January 7, 2020, the Chinese Center for Disease Control and Prevention (CCDCP) named the disease Acute Respiratory Syndrome as Coronavirus 2 (SARS-CoV-2) and the World Health Organization (WHO) as COVID-19(2) During the Chinese Spring Festival on January 23, public transport was suspended in Wuhan and all cities in Hubei Province due to large crowds lowering the social sharing threat(3). With the gradual expansion of COVID-19, professional sensitivities, guidelines, and standards were established to facilitate infection prevention, diagnosis, and treatment (4).

In December 2019, the first case has been registered, and from December 18, 2019 to December 29, 2019, one in five patients admitted to the hospital with acute respiratory infection syndrome died $(5,6)$. Some features of the COVID-19 virus are not yet fully known, and among the objected patients, COVID-19 was newly found in saliva(7). 
Progress can hardly be forecastof economic anxiety and to evaluate its underlying mechanisms in the context of an epidemic when relying on historical accounts(8).The COVID-19 epidemic caused a greater uncertainty than the financial crisis of 2008-09 and is more similar to 1929-1933(9).Individual livelihoods, business, industry and the entire economy are likely to collapse due to COVID-19(10). Chinese markets have also begun to rebound, with U.S. markets reaching new highs after initial sales closed at the end of January for COVID-19(11).Techniques in South Korea appear somewhat more restrictive than in order(12). More than 20.5 million Americans applied for unemployment insurance in April, that all-time record and the highest national unemployment monthly rate since 1948, at $14.7 \%$ (13). Bangladesh Bureau of Statistics (BBS), the researchers have run simulations which reveal that with a negative income shock of $25 \%$, the overall poverty rate will be $40.9 \%$, which means another $20.4 \%$ population will fall into poverty (14).In this situation, in developing countries like Bangladesh, the coronavirus can be a threat to the economy (15).

Different opinions have been expressed in different countries about the prevalence of COVID-19 (16). In this paper, we show the coronavirus outbreak situation in Bangladesh on the comprehensive data verification, selection, and evaluation of COVID-19 in Bangladesh and its implications for the future, what to do to address and prevent the COVID-19 challenge, and effective treatment against the coronavirus (COVID-19).

\section{Review,andcomparison and feedback of overall data of Covid-19 in Bangladesh:}

The number of people infected and dying from the coronavirus epidemic is constantly increasing worldwide. Because, COVID-19is a direct propagation from human to human by forward touch and by droplets in the air(17).Fever, cough and tiredness are the most common signs of early COVID-19 disease and other signs include sputum generation, headache, hemoptysis, vomiting, dyspnea and lymphopenia (18). Table-1 provide various data to compare the overall situation of coronavirus in Bangladesh and other countries in South Asia and Fig-1 data have been provided to review the current overall situation of COVID-19 countries with more coronavirus attacks in the world along with Bangladesh.

Here in Table-1 it is seen that the South Asian country of Maldives has the highest number of infected 5483 people per million population and the second highest number is 1241 in Bangladesh and the lowest is 113 in Bhutan and also added that Afghanistan has the highest number of total death 30 people per million of population and the $5^{\text {th }}$ highest number is 16 in Bangladesh and the lowest is zero in Bhutan. A comparison of Bangladesh with South Asian countries in Fig-1 also shows that Bangladesh has the second lowest of total COVID-19 test 6241 per million of the total population and the lowest 1241 in Afghanistan. Since the number of coronavirus testing is very low compared to the total population in Bangladesh, the average amount of death and amountof infections per one million population is significantly higher than in South Asian countries. Full amount of recuperation in Bangladesh is 111642 which is satisfactory though it is not possible to consider the situation of overall COVID-19 of a country with the amount of recuperation. India has the highest amount of active cases among South Asian countries and Bangladesh is in the second position at 90275. In India, the critical number is 6944 , which is very worrying.

\begin{tabular}{|c|l|l|l|l|l|l|}
\hline $\begin{array}{c}\text { received data } \\
\text { on July } 19\end{array}$ & $\begin{array}{l}\text { Total cases } \\
\text { /1 M Pop. }\end{array}$ & $\begin{array}{l}\text { Total death } \\
\text { /1 M Pop. }\end{array}$ & $\begin{array}{l}\text { Total test } \\
\text { /1 M Pop. }\end{array}$ & $\begin{array}{c}\text { Total } \\
\text { recovered }\end{array}$ & $\begin{array}{l}\text { Active } \\
\text { cases }\end{array}$ & $\begin{array}{l}\text { Serious } \\
\text { critical }\end{array}$ \\
\hline
\end{tabular}




\begin{tabular}{|l|l|l|l|l|l|l|}
\hline Afghanistan & 910 & 30 & 2,150 & 23,634 & 10660 & 31 \\
\hline Bangladesh & $\mathbf{1 2 4 1}$ & $\mathbf{1 6}$ & $\mathbf{6 , 2 4 1}$ & $\mathbf{1 1 6 4 2}$ & $\mathbf{9 0 2 6 5}$ & $\mathbf{1}$ \\
\hline Bhutan & 113 & 0 & 52,202 & 80 & 7 & 0 \\
\hline Maldives & 5,483 & 28 & 124,344 & 2,362 & 589 & 12 \\
\hline Nepal & 606 & 1 & 21,536 & 11,695 & 5,923 & 0 \\
\hline India & 810 & 20 & 9,989 & 700,399 & 390205 & 8,944 \\
\hline Pakistan & 1,192 & 25 & 7,788 & 204,276 & 53,652 & 1,763 \\
\hline Sri Lanka & 127 & 0.5 & 6,327 & 2,035 & 678 & 1 \\
\hline
\end{tabular}

Table-1: The latest situation of COVID-19 in South Asian countries till June 26 (19).

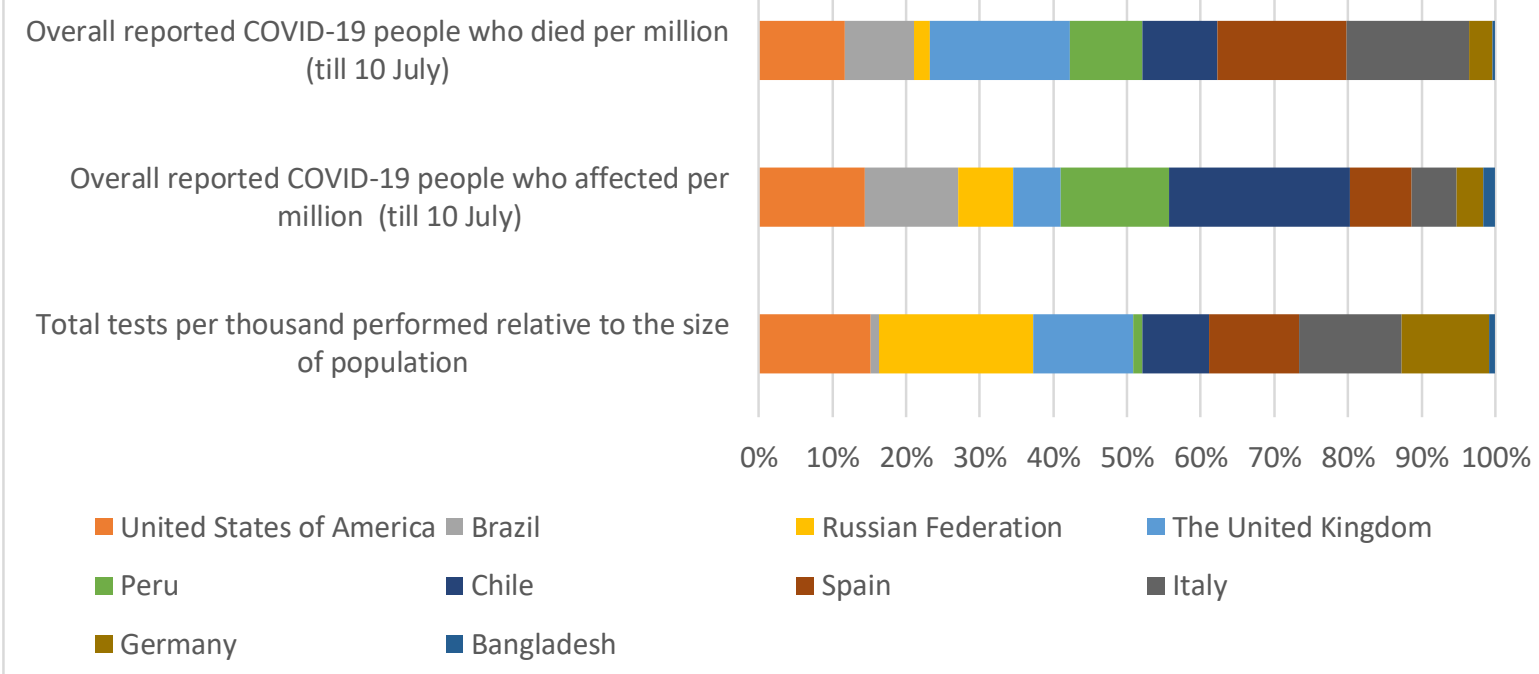

Fig-1: Data for review of the current COVID-19 overall situation of countries with more coronavirus attacks in the world with Bangladesh (20)

Fig-1 shows that compared to the total population of COVID-19, the percentage of Tests per thousand is the lowest in Bangladesh at 5.51 and Brazil is in the second position at 6.96. Since the number of COVID-19 tests in Bangladesh is much less than other countries, the total confirmed cases and overall reported COVID-19 people who died per million people are less than $1,065.61$ and 13.59 respectively.

The incidence of COVID-19 in Bangladesh in Fig-3 is much higher than in South Asia and around The World, but the mortality rate is slightly lower. In Fig-2 gives an idea of the total number of deaths from coronavirus infection in the world every 10 days from January 21 to June 19 and indicates the time of the highest number of deaths. 


\section{Total death till 29 June}



Fig-2: Bar chart for death COVID-19 people from 21 January to 29 June in the world (21).

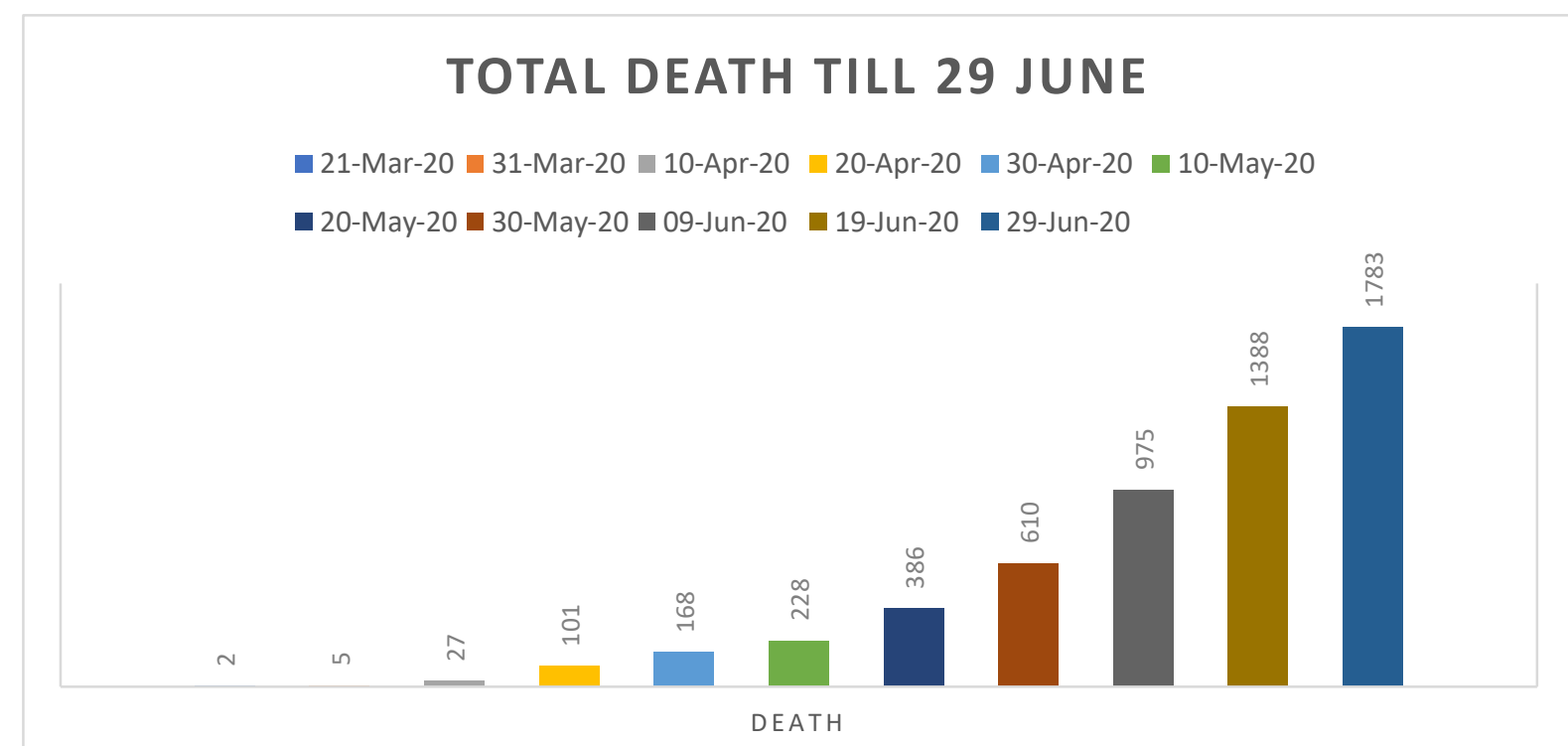

Fig-3: Bar chart for death COVID-19 people from 18 March to 29 June in Bangladesh (22).

Data from Fig-3 are taken from the Pathology Disease Control and Research (IEDCR) website. Fig- 4 gives an idea of the total number of deaths from coronavirus infection in the world every 10 days from $18^{\text {th }}$ March to June $29^{\text {th }}$ and indicates the time of the highest number of deaths. From this chart it can be inferred that the death rate due to coronavirus in Bangladesh is less than in other developed countries of the world but the infection is increasing day by day. The United Nations has called on South Korea to follow in South Korea's footsteps in dealing with the epidemic and also called South Korea's move a "green deal" (23).

As of $18^{\text {th }}$ July, according to Institute of Epidemiology, Disease Control and Research (IEDCR) of Bangladesh whole1,028,299 samples were tested and 204,525 were infected, $\mathbf{2 , 6 1 8}$ were death and 111,644 were recovered (24). The information provides infection rate is 
$19.8 \%$, recovery rate is $54.58 \%$, and mortality rate is $1.28 \%$. As of $30^{\text {th }}$ June 2020 , according to Bangladesh Medical Association (BMA),total 5690 doctors, nurses and health workers have been affected by coronavirus (COVID-19), including 1995 doctors, 1536 nurses and 2159 other health workers and most of the health workers including doctors, nurses and staff are affected by coronavirus due to low quality masks and Personal Protecting Equipment (PPE) (25). If the total number of infection in coronavirus in Bangladesh 204,525 and only doctor is about 1995 till $18^{\text {th }}$ July then the rate of infection among doctors is $\mathbf{0 . 9 7 5} \%(25,26)$.

\begin{tabular}{|l|l|l|}
\hline Division & Affected of Doctor & Percentage \\
\hline Dhaka & 993 & 49.65 \\
\hline Chittagong & 420 & 21 \\
\hline Sylhet & 192 & 9.6 \\
\hline Mymensingh & 149 & 7.45 \\
\hline Khulna & 95 & 4.75 \\
\hline Rangpur & 67 & 3.35 \\
\hline Barisal & 50 & 2.5 \\
\hline Rajshahi & 29 & 1.45 \\
\hline & Total:1995 & \\
\hline
\end{tabular}

Table-2: Percentage of doctors in Bangladesh according to the Division (25).

From Table-2, the data is extremely sad and dangerous because the condition of the affected patients is more deplorable if the condition of the doctors in such. Bangladesh having only one doctor for every 1847 peoples medical treatment, although the government is trying to deal with it efficiently (27).

\section{In the present situation of coronavirus in Bangladesh}

On 5 April Bangladesh reported 18 new cases, an increase of 26 percent over the previous day and an increase of 20 percent over the day to the present, which is a sharp rise in cases (28). Bangladesh crosses the figure of 100 confirmed cases on $6^{\text {th }}$ April, 1,000 confirmed cases on $14^{\text {th }}$ April, 10000 confirmed cases on $3^{\text {th }}$ May, 25000 confirmed cases on $18^{\text {th }}$ May, 50000 confirmed cases on 1 th June, 75000 confirmed cases on $11^{\text {th }}$ June and 100000 confirmed cases on $18^{\text {th }}$ June (29). 


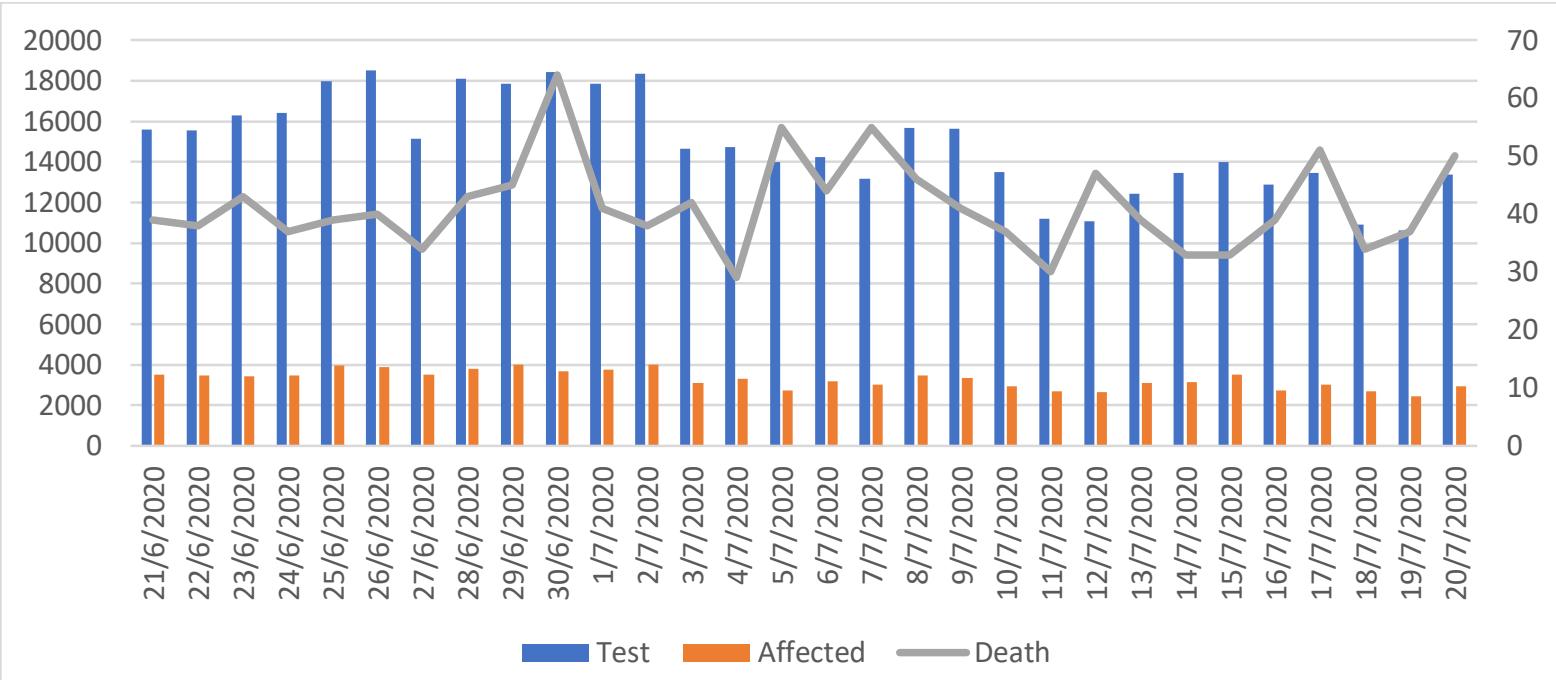

Fig-4: From 21 June to 20 July, till the number of daily COVID-19 tests, infections and death in Bangladesh is arranged (30).

Fig-4 shows that with the increase of COVID-19 test for 30 days from 21 June to 20 July, the number of infected people is increasing at a very proportional rate. The rate at which tests are being conducted every day is not enough and it is not a picture of the whole country. The death toll is not commensurate with the amount of COVID-19 tested andtainted, but the number of deaths in the last one month was between a minimum of 29 and a maximum of 74 . The country is still not at the peak of transition. If the number of tests is increased and the general holidays are also increased the situation may become going for the better. If not, the highest number of deaths and patients will be seen quickly. Imperial College London reported that Bangladesh's top will die as many as 10,000 in a single day in September and October but government action could reduce it (31).

\section{Activities and preparation of medical system in Bangladesh:}

In Bangladesh the highest mortality rate of doctors in the world (32). Doctors are seeing this condition as worrying. The overall mismanagement of the health sector is becoming more evident especially at this time. In this situation, a new plan is needed to give proper protection to the front-line fighters. Because physicians need to play a responsible role in dealing with the current crisis for coronavirus, as well as build trust by ensuring the necessary benefits.

Statistically, it is 14 percent. It is important to understand that the situation is alarming and that the actual data needs to be verified through extensive testing (33). Till now The Ministry of Health of Bangladesh could not take any effective steps to deal with corona properly. The mistakes that the Ministry of Health is making include-

First; The Ministry of Health has not taken any plan to increase the number of coronavirus testing. Because the number of tests is being increases as the number of patients increases (34). If this situation continues, the health system will be at greater risk instead of preventing the coronavirus.

Secondly; The Ministry of Health has not been able to set up a separate hospital to treat patients infected with the coronavirus, which is why private hospitals are becoming at risk (35). If such a situation arises, it is feared that the citizens of this country will lose their last resort to get the minimum treatment. 
Third; The healthcare workers have been suffering from a crisis of medical supplies and food. The masks provided at these centre are not N95 or equivalent masks (36).

The Department of Health in United States of America(USA) is giving wrong information about the rate of coronavirus infection, death and recovery in the country (37). If as the same, Bangladesh will go to enter a complicated situation in dealing with Corona and every step is forgotten. From which the path of liberation is very difficult and it may cost a lot.

Since the COVID-19 infection in Bangladesh, health workers have been the mostly affected. Situation has brought panic among the doctors and the doctors are raising the issue of their safety. Bangladesh has not yet made such preparations as there is an alternative team in all countries. As a result, if more physicians are infected, health workers and physicians may not be found to provide treatment.

\section{Three important features of the medical system in Bangladesh:}

First, a large part of our medical system is dependent on private hospitals, and private hospitals cover large of our total medical system (38). There have been frequent complaints of patients being turned away from various hospitals after the onset of COVID-19 infection (39). However, analysis of various data large proportion are met through treatment abroad (40). Concerns continue over the state of the private medical system in the wake of the coronavirus epidemic in Bangladesh. As a result, medical care is in crisis.

Second, private hospitals in Bangladesh are not treating people properly because people will come to private hospitals for corona tests if they have minor symptoms, which will increase the risk of infection in private hospitals. As a result, coronavirus infections may increase in private hospitals.

Third, ordinary people go to private hospitals to hide their symptoms of shortness of breath and other symptoms of coronavirus and talk about heart disease and difficulty in breathing. That is why there is a terrible risk of corona infection. This is creating mistrust of the patients with the health workers. If this continues, all kinds of treatment can be stopped.

\section{To protect coronavirus (COVID-19) in the perspective of Bangladesh it should,}

1. It is advisable to isolate confirmed or suspected cases with mild illness at home (41). Restricting propagation between human and human is essential to prevent the spread of infection and to reduce secondary infections among healthcare workers and to prevent further spread from China (42).

2. Ensure that all doctors, nurses and health workers working at the entrance of Non COVID19 Hospital are provided with suitable PPE, N-95 or equivalent masks by introducing Triage System with shortest possible time.

3. Emergency medicine departments need to be strengthened to implement strict hygienic measures to control infection prevention(1). Accommodation of doctors, nurses and other 
health workers working in all public and private hospitals, provision of necessary food and transportation to the hospital.

4.

(I) Listing of essentials, marketing by calculation and social distance must be maintained during this time.

(II) Masks and gloves should be worn and disinfected using soap and water if necessary.

(III) Disinfectant and shoes at the entrance of the house. Precautions for use

(IV) Stay away from other family members, it should be strictly adhered to until completely disinfected.

(V) The standard rule for hand washing is to wash hands with soap and water for at least 20 seconds, and if soap and water are not procurable, use disinfectant of alcohol with at least $60 \%$ alcohol (43).

(Vi) Market bags or packets of soap and water or disinfect water detail.

\section{Public Health Invented 'GR COVID-19 Rapid. Bolt Immunity' Kit for coronavirus (COVID-19):}

The test kit 'GR COVID-19 dot blot' developed by the Gonoshasthaya Kendra's can be used to identify antigen-antibodies at the same time, said the chief microbiologist of the team who invented the kit. Bijon Kumar Sheel(44). Once the virus enters the human body, within minutes the body's immune system interferes with its innate response by helping granulocytes, scavenger cells, and blood and lymphatic system killer cells to fight the virus (45). The treatment given to the patient drops the immune system in the body of the infected person, so it is too late for the immune system to come. If it is positive, the antibody will be positive (46).

The kit uses the Rapid Blot-Dot technique to detect coronavirus positive cases within 15 minutes(44). Public health kits are tested from blood samples. A drop of blood serum 'GR COVID-19 dot blot' in a rapid testing kit will give a specific color(47). The technique looks for antibodies created in the body in response to the virus infection (48). It can be seen together in a public health kit, antigen, antibody and possible to identify $70 \%$ of the patients who have had COVID-19 disease before (49). Gonoshasthaya Kendra's founder and trustee Dr.Zafrullah Chowdhury, who tested COVID-19 positive according to the organisation's newly developed Rapid Dot Blot test, has been receiving plasma therapy by taking 200 millilitre serum from a recovered COVID-19 patient on 26 May Tuesday afternoonandfound that his body is developing some antibodies (50).

Public health invented coronavirus 'GR COVID-19 Rapid Dot Bolt Immunity' kit has not yet been approved testing as the Ministry of Health because,"70 percent of patients who have previously had COVID-19 disease can be identified" said Bangabandhu Sheikh Mujib Medical University (BSMMU) (51).

Despite its importance in many countries around the world, no government agency or the Department of Drug Administration went to the Gonoshasthaya Kendra to receive the kit, except Centres for Disease Control and Prevention (CDC), a US-based research institute for coronavirus detection (52). 
In consultation with the World Health Organization on the importance of coronavirus identification. Extensively tested, the importance of the 'GR COVID-19 dot blot' kit invented by the public health centre is immense. The best part of this rapid kit is it's cheap (approximately \$3) to produce unlike the RT-PCR testing kit which one is expensive costs about $\$ 120$ to $\$ 130$ (44).

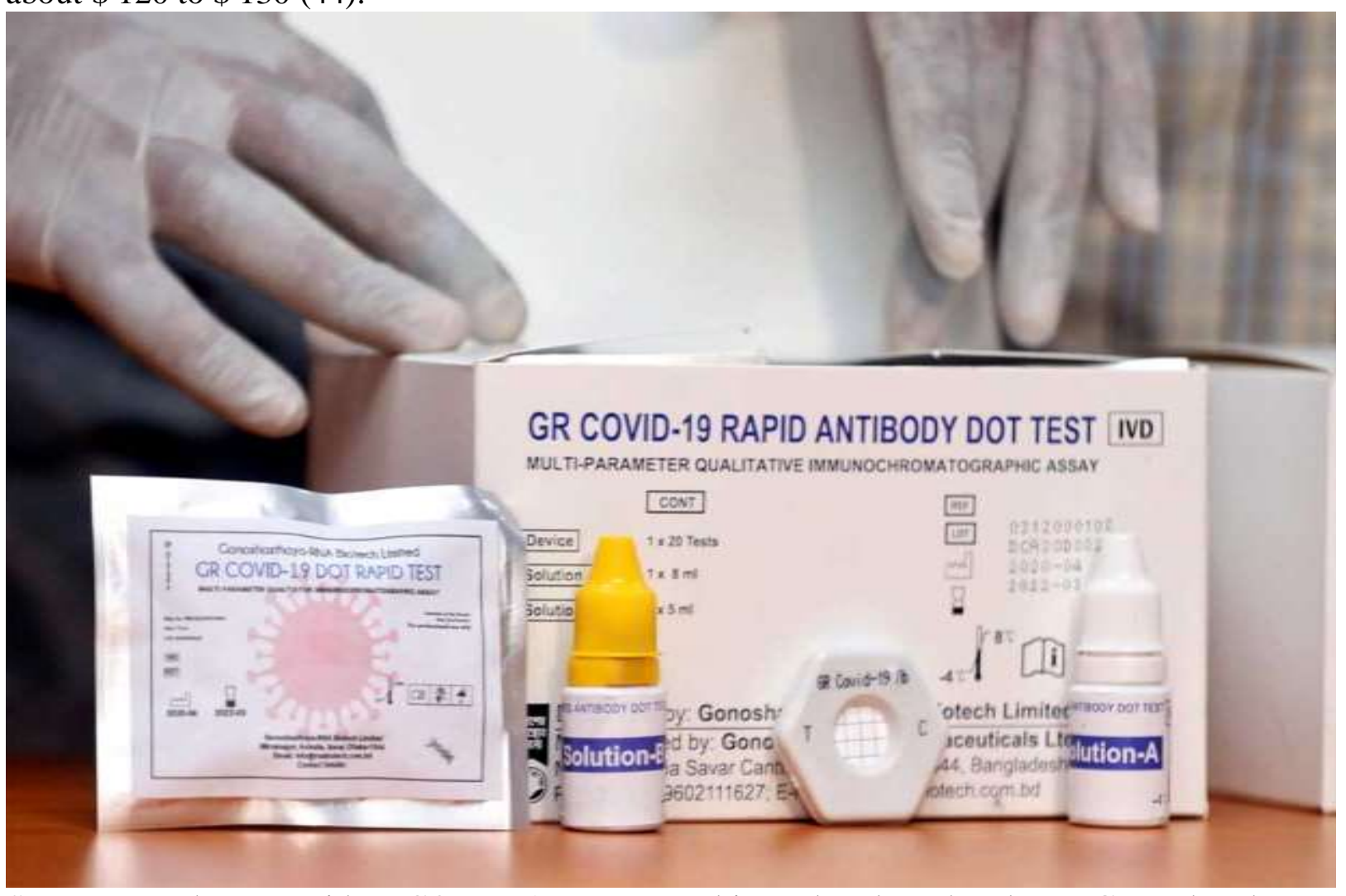

Source: The rapid COVID-19 test kit developed by Gonoshasthya Kendra RajibDhar/Dhaka Tribune(49).

Dr.Zafrullah Chowdhury said the European Union had shown interest in importing their kits(53). GonoshasthayaRNA Biotech Limited, a subsidiary of Gonoshasthaya Kendra, with the help of experts from Singapore, invented the kit called "GonoshasthayaRapid.blot"(54).

\section{Various drugs and medical systems that are being used for COVID-19 treatment in Bangladesh and some of which are being researched:}

Since COVID-19 is currently being used as a symptomatic and supportive care until any standard and hundred percent effective treatment, efforts are being made to prevent vital symptoms as much as possible (e.g., oxygen saturation and blood pressure) and to treat complications (e.g., minor infections or organ failure) (55). There are a number of antiviral drugs and treatments that have been found in the world that are not completely effective, but they are used to prevent COVID-19. Favipiravir, Remdesivir, Hydroxychloroquine, Lopinavir-Ritonavir and Ribavirin are some of them (56). Most COVID-19 patients took antiviral therapy in China (57). To prevent the symptoms and cause of death of COVID-19, a number of potential experimental treatments are underway,

\section{Ivermectin and Doxycycline:}


Bangladeshi doctors Bangladesh Medical College Hospital (BMCH) Professor Dr Md Tarek Alam claim to have found effective drugs used antiprotozoal medicine called Ivermectin in a single dose with Doxycycline yielded miraculous result in curing his patients with COVID-19 treatment (58). In all 120 cases, their oxygen needs decreased and they returned home within two to three days (59).

\section{Ivermectin:}

Ivermectin an Food and Drug Administration(FDA) authorized anti parasitic and antiviral activity in vitro is an inhibitor of the causative virus (SARS-CoV-2) (60). Over the next 2448 hours Ivermectin is regulate virus transcript and it stopped the SARS-CoV-2 virus growing in cell culture (61). The key explanation for a single dose is to eliminate all viral RNA by 48 hours and that there was a substantial decrease even at 24 hours (62). People diagnosed with COVID-19 will consider a multiple supplemental dosing protocol under the latest permitted use of Ivermectin after clinical trials with Ivermectin(63). Ivermectin is an anti-parasitic medication authorized by the U.S. Food and Drug Administration that has also been shown to be impactful in vitro against a wide variety of viruses involving HIV, Dengue, Influenza and Zika in periods when we are facing a global pandemic and no authorized treatment is available (64). Ivermectin is an emerging oral antiscabietic that is as safe and effective as the topical (65). It should be given as a single dose (no. of $6 \mathrm{mg}$ tablet 2) with a full glass of water $(240 \mathrm{ml})$ on an empty stomach (1 hour before breakfast) (66) .Common side effects are nausea, vomiting, diarrhoea, muscle or joint pain, fever, tiredness, itching, eye redness $(66,67)$. At present this medicine is being given to people above 18 years of age. In Bangladesh, Delta Pharmaceuticals Limited manufactures and markets Ivermectin BP 6 mg / tablet called Sacabo 6 and Beximco Pharmaceuticals Limited Ivera 6or12, Popular Pharmaceuticals Limited Imec 6 etc. are existed (68). Invermectin is very good news for garment workers in Bangladesh and for people suffering from lower middle class coronavirus (COVID-19) in this country, because Delta Pharmaceuticals' Scabo 6 requires only 5 taka each, along with paracetamol in case of fever and Implex of Azithromycin in case of heart disease which within reach $(69,70)$.

\section{Plasma therapy (CP):}

Convalescent plasma obtained from patients retrieved (or survivors) to patients with COVID19 retain incineration antibodies against COVID-19(71). While the problem remains to be addressed with a conclusive treatment or vaccine for this lethal viral infection, an experimental study relating to the treatment of convalescent plasma (CP) arises as an array of light for the battle against SARS-CoV-2 infection (72).Convalescent plasma (CP) medication or hyper immune globin therapy has already been handed-down in Germany, France, the USA, Iran as well as many other nations around the globe to handle COVID19(12). Convalescent plasma treatment is more authoritative than intenseequilibriumof hormonal knock in patients with SARS, attempting to reduce death rates and inpatient condition(73). In comparison, a number of studies showed a shorter hospitalization and a lower mortality rate of patients consuming convalescent plasma than people undergoing plasma treatment (74-76). A limited study of MERS transit indicated that the neutralizing antibody titrate would achieve 1:80 for effective medication with $\mathrm{CP}$ and the first major 
explanation is CP-reduced clinical therapy and neutralization (77). Since both SARS-CoV and the same SARS-CoV-2 sequence of sick persons i.e. patients have both high scalability and virological homology, the treatment of the badly affected COVID-19 patients may be convincing for $\mathrm{CP}$ therapy $(60,78)$. In patients with 36 mo post-sickness disease, unique neutralized antibodies were degraded 4 mo slowly, reaching undetectable levels in $25.6 \%$ (IgG) and $16.1 \%$ (neutralizing antibodies) (79). A MERS-CoV analysis revealed a very small (2.7percent) prevalence of MERS-CoV IgG seroreactivity, where the antibodies titter rapidly decreased within $3 \mathrm{mo}$ and exposed healthcare staff and patients were also exported (80). For this procedure, around one litre of plasma will be collected, where approximately only 250 $\mathrm{mL}$ of plasma is required for one patient (81). COVID-19 sufferers should receive ABOConvalescent Plasma advancement consistent $(200 \mathrm{~mL}$ on every stages)over a period of at least 30 minutes (82). Researchers found that patients were negative in the SARS-CoV-2 nucleic acid analyze after the introduction of CP therapy, increased oxygen saturation and lymphocytic counts and also enhanced organ function (83). We can say that convalescent plasma therapy may be an effective therapy to improve the clinical outcomes of COVID-19 patients.

\section{Remdesivir:}

The United States first drug discovery led to the use of Remdesivir as a 'unique pharmaceutical' and China took immediate measures to put Remdesivir in clinical trials and use it in therapeutic coronavirus (COVID-19) therapy (84). Bangladesh has become the first country in the world to sell a generic version of Remdesivirfor the treatment of COVID19(85).Remdesivir clearly shows promise in combating new coronavirus, has been authorized for emergency use in the United States, but Remdesivir is a expensive medication and many argue that people usually cannot afford to get BeximcoRemdesivir free from these Govt. hospitals in Bangladesh (86). Admitted hospitalized adults, including COVID-19, had better recovery times and reduced Remdesivir placebo as evidence of lower respiratory tract infections (87). Remdesivir has demonstrated therapeutic and prophylactic effectiveness in nonclinical coronavirus models and has broad spectrum activity against filoviruses (e.g., Ebola) and coronaviruses (e.g., SARS-CoV and Middle East respiratory syndrome coronavirus [MERS-CoV]) (88).

\section{Conclusion:}

The main goal now is to prevent the COVID-19 situation crisis in Bangladesh and the government needs to be stricter and responsible the people need to be reminded to prohibit the spread of the infection. The scope of COVID-19 test needs to be further enhanced by ensuring public health services, adherence to social distances, adequate and quality regular PPE supply to Corona-facing veteran doctors, compliance with home quarantine, planned measures with strict maintenance, planned measures and proper knowledge of COVID-19. Growth, use of experience and corruption must be strictly suppressed. Above all, by properly balancing the government, citizens and experts, it will be able to mitigate the situation by building resistance against the deadly virus.

\section{Reference:}

1. Cascella M, Rajnik M, Cuomo A, Dulebohn SC, Di Napoli R. Features, Evaluation 
and Treatment Coronavirus (COVID-19) [Internet]. StatPearls. StatPearls Publishing; 2020 [cited 2020 Jul 6]. Available from: http://www.ncbi.nlm.nih.gov/pubmed/32150360

2. Sohrabi C, Alsafi Z, O’Neill N, Khan M, Kerwan A, Al-Jabir A, et al. World Health Organization declares global emergency: A review of the 2019 novel coronavirus (COVID-19). Vol. 76, International Journal of Surgery. Elsevier Ltd; 2020. p. 71-6.

3. Jiang F, Deng L, Zhang L, Cai Y, Cheung CW, Xia Z. Review of the Clinical Characteristics of Coronavirus Disease 2019 (COVID-19). J Gen Intern Med. 2020;35(5):1545-9.

4. Pan F, Ye T, Sun P, Gui S, Liang B, Li L, et al. Time course of lung changes at chest CT during recovery from Coronavirus disease 2019 (COVID-19). Radiology [Internet]. 2020 Jun 1 [cited 2020 Jul 6];295(3):715-21. Available from: https://doi.org/10.1148/radiol.2020200370

5. Du Toit A. Outbreak of a novel coronavirus [Internet]. Vol. 18, Nature Reviews Microbiology. Nature Research; 2020 [cited 2020 Jul 6]. p. 123-123. Available from: https://www.nature.com/articles/s41579-020-0332-0

6. Ren LL, Wang YM, Wu ZQ, Xiang ZC, Guo L, Xu T, et al. Identification of a novel coronavirus causing severe pneumonia in human: a descriptive study. Chin Med J (Engl) [Internet]. 2020 May 5 [cited 2020 Jul 6];133(9):1015-24. Available from: http://journals.lww.com/10.1097/CM9.0000000000000722

7. Kai-wang K, Tak O, Tsang Y, Yip CC, Choi CY, Kandamby DH. Consistent detection of 2019 novel coronavirus in saliva. Clin Infect Dis [Internet]. 2020 [cited 2020 Jul 6];1-14. Available from: https://academic.oup.com/cid/articleabstract/doi/10.1093/cid/ciaa149/5734265

8. Fetzer T, Hensel L, Hermle J, Roth C. Coronavirus Perceptions and Economic Anxiety. Rev Econ Stat [Internet]. 2020 [cited 2020 Jul 6];1-36. Available from: https://doi.org/10.1162/rest_a_00946

9. Baker S, Bloom N, Davis S, Terry S. COVID-Induced Economic Uncertainty. Natl Bur Econ Res [Internet]. 2020 Apr [cited 2020 Jul 7]; Available from: http://www.nber.org/papers/w26983.pdf

10. Laing T. The economic impact of the Coronavirus 2019 (Covid-2019): Implications for the mining industry [Internet]. Vol. 7, Extractive Industries and Society. Elsevier Ltd; 2020 [cited 2020 Jul 7]. p. 580-2. Available from: https://linkinghub.elsevier.com/retrieve/pii/S2214790X2030126X

11. Baldwin R, Mauro BW di. Economics in the Time of COVID-19 [Internet]. Economics in the Time of COVID-19. 2020 [cited 2020 Jul 7]. 105-109 p. Available from: www.cepr.org

12. Mahmud M, Shamim Hasan M, Riajul Islam Sardar M, Babul Miah M. Use of different Drugs and Plasma Therapy against Treatment of COVID-19 : South Koreabased Overall Perspective. Bangladesh Army Univ Eng Technol [Internet]. 2020;2(2):97-103. Available from: http://journal.bauet.ac.bd/wpcontent/uploads/2020/08/Manuscript-10.pdf

13. Tappe A. April jobs report 2020: Unemployment surges after colossal layoffs in April. CNN Business [Internet]. 2020 May 8 [cited 2020 Jul 7]; Available from: https://edition.cnn.com/2020/05/08/economy/april-jobs-report-2020coronavirus/index.html

14. SANEM researchers assess poverty impacts of COVID-19 [Internet]. South Asian Network on Economic Modeling. 2020 [cited 2020 Jul 7]. Available from: http://sanemnet.org/sanem-researchers-assess-poverty-impacts-of-covid-19/

15. Alam M, Alam M, Nazir K, Bhuiyan M. The emergence of novel coronavirus disease 
(COVID-19) in Bangladesh: Present status, challenges, and future management. J Adv Vet Anim Res [Internet]. 2020 [cited 2020 Jul 7];7(2):198. Available from: http://bdvets.org/javar/198http://doi.org/10.5455/javar.2020.g410

16. Talukder AK, Sheikh B, Rahman M, Sheikh B, Rahman M, Engineering G, et al. Tackling the Pandemic COVID-19: the Bangladesh Perspective. 2020 Apr 21 [cited $2020 \mathrm{Jul}$ 7];(April):1-18. Available from: www.preprints.org

17. Repici A, Maselli R, Colombo M, Gabbiadini R, Spadaccini M, Anderloni A, et al. Coronavirus (COVID-19) outbreak: what the department of endoscopy should know. Gastrointest Endosc [Internet]. 2020 Jul [cited 2020 Jul 8];92(1):192-7. Available from: https://linkinghub.elsevier.com/retrieve/pii/S0016510720302455

18. Rothan HA, Byrareddy SN. The epidemiology and pathogenesis of coronavirus disease (COVID-19) outbreak. J Autoimmun [Internet]. 2020 May 1 [cited 2020 Jul 8];109:102433. Available from: https://linkinghub.elsevier.com/retrieve/pii/S0896841120300469

19. Worldometer. Coronavirus Update (Live): Cases and Deaths from COVID-19 Virus Pandemic [Internet]. Worldometers. 2020 [cited 2020 Jun 26]. p. 1. Available from: https://www.worldometers.info/coronavirus/

20. Ritchie H, Ortiz-Ospina E, Beltekian D, Mathieu E, Hasell J, Macdonald B, et al. Coronavirus (COVID-19)Testing,Cases,Deaths - Statistics and Research [Internet]. Our World in Data. 2020 [cited 2020 Jul 11]. Available from:

https://ourworldindata.org/covid-cases\#world-maps-confirmed-cases-relative-to-thesize-of-the-population

21. Organization WH. WHO Coronavirus Disease (COVID-19) Dashboard [Internet]. World Health Organization. 2020 [cited 2020 Jun 29]. Available from: https://covid19.who.int/

22. Institute of Epidemiology DC and R (IEDCR). Covid-19 Status for Bangladesh|Death [Internet]. Covid-19 Daily Trends for Bangladesh. 2020 [cited 2020 Jun 29]. Available from: https://www.iedcr.gov.bd/

23. 'Remarkable example: UN chief says world should follow South Korea on Covid-19 fight - world news - Hindustan Times [Internet]. [cited 2020 Jun 23]. Available from: https://www.hindustantimes.com/world-news/remarkable-example-un-chief-saysworld-should-follow-south-korea-on-covid-19-fight/story-

WojyJDZIucGctjMeL2HdvN.html

24. IDARE. Covid-19 Vital Statistics [Internet]. Institute of Epidemiology, Disease Control and Research (IEDCR). 2020 [cited 2020 Jun 29]. p. 1. Available from: https://iedcr.gov.bd/

25. Bangladesh Medical Association(BMA). Sl. Division S1. District Total Doctor Total Nurse Total Staff District Wise Total Number of Affected Doctor, Nurse \& Staff (COVID 19+) [Internet]. 2020 [cited 2020 Jul 19]. Available from: https://bma.org.bd/

26. Coronavirus statistics: Latest numbers on COVID-19 cases and deaths | Euronews [Internet]. [cited $2020 \mathrm{Jul} 1$ 1]. Available from:

https://www.euronews.com/2020/06/30/covid-19-coronavirus-breakdown-of-deathsand-infections-worldwide

27. One doctor for every 1847 people in Bangladesh [Internet]. [cited 2020 Jun 23]. Available from: https://en.prothomalo.com/lifestyle/One-doctor-for-every-1847people-in-Bangladesh

28. Wikipedia. COVID-19 pandemic in Bangladesh [Internet]. May 27, 2020. 2020 [cited 2020 Jun 29]. p. 70-2. Available from: https://en.wikipedia.org/wiki/COVID19_pandemic_in_Bangladesh

29. Local contact. Institute of Epidemiology, Disease Control and Research (IEDCR) 
[Internet]. 2019 [cited 2020 Jun 23]. Available from: https://www.iedcr.gov.bd/website/

30. HEOC \& Control Room, IEDCR D. Coronavirus COVID-19 Dashboard, 2020 [Internet]. Directorate General of Health Services (DGHS). 2020 [cited 2020 Jun 29]. Available from: http://103.247.238.92/webportal/pages/covid19.php

31. Covid-19 Scenario Analysis Tool [Internet]. [cited 2020 Jun 23]. Available from: https://covidsim.org/v2.20200618/?place=Bangladesh

32. Syed Manzur E, Shah Husain I. Coronavirus: Doctors' mortality rate in BD 'highest in the world' [Internet]. The Financial Express. [cited 2020 Jun 29]. Available from: https://thefinancialexpress.com.bd/national/coronavirus-doctors-mortality-rate-in-bdhighest-in-the-world-1592665440

33. Max Roser, Hannah Ritchie, Esteban Ortiz-Ospina, Joe Hasell. Coronavirus Disease (COVID-19) - Statistics and Research - Our World in Data. Univ Oxford [Internet]. 2020;2020:1-42. Available from: https://ourworldindata.org/coronavirus

34. Sujan MA; Bin Habib W. Test rate still very low | The Daily Star [Internet]. The Daily Star. 2020 [cited 2020 Jun 23]. Available from:

https://www.thedailystar.net/frontpage/news/test-rate-still-very-low-1901827

35. Tajmim T. Coronavirus: Bangladeshi private hospitals unable to treat COVID-19|The Business Standard. The Business Standard [Internet]. [cited 2020 Jun 23]; Available from: https://tbsnews.net/bangladesh/health/private-hospitals-unable-unwilling-treatcoronavirus-patients-54169

36. Ullah S. Healthcare workers in Chattogram dissatisfied over low-quality PPE | The Business Standard [Internet]. The Business Standard. [cited 2020 Jun 23]. Available from: https://tbsnews.net/coronavirus-chronicle/covid-19-bangladesh/healthcareworkers-chattogram-dissatisfied-over-low

37. Madrigal AC. The Official Coronavirus Numbers Are Wrong, and Everyone Knows It - Government Executive [Internet]. The Atlantic. [cited 2020 Jun 23]. Available from: https://www.govexec.com/management/2020/03/official-coronavirus-numbers-arewrong-and-everyone-knows-it/163508/

38. World Health Organization. Health Facility Survey. World Health. 2003;1:1.

39. Kashem A. Private hospitals to lose licence for refusing emergency patients or anybody | The Business Standard [Internet]. The Business Standard. [cited 2020 Jun 23]. Available from: https://tbsnews.net/bangladesh/health/private-hospitals-loselicence-refusing-covid-19-patients-80218

40. Andaleeb SS, Siddiqui N, Khandakar S. Patient satisfaction with health services in Bangladesh. Health Policy Plan. 2007;22(4):263-73.

41. Singhal T. A Review of Coronavirus Disease-2019 (COVID-19) [Internet]. Vol. 87, Indian Journal of Pediatrics. Springer; 2020 [cited 2020 Jul 9]. p. 281-6. Available from: https://doi.org/10.1007/s12098-020-03263-6

42. Lai CC, Shih TP, Ko WC, Tang HJ, Hsueh PR. Severe acute respiratory syndrome coronavirus 2 (SARS-CoV-2) and coronavirus disease-2019 (COVID-19): The epidemic and the challenges. Vol. 55, International Journal of Antimicrobial Agents. Elsevier B.V.; 2020. p. 105924.

43. Giwa AL, Desai A, Duca A. Novel 2019 coronavirus SARS-CoV-2 (COVID-19): An updated overview for emergency clinicians. Emerg Med Pract [Internet]. 2020 [cited $2020 \mathrm{Jul}$ 10];22(5):1-28. Available from: https://www.coronavirusdisease.nl/wpcontent/uploads/2020/03/Coronavirus-COVID-19.pdf

44. Mahmud F. Bangladesh scientists create $\$ 3$ kit . Can it help detect Similar kit developed in China. Aljazeera [Internet]. 2020 Mar 24 [cited 2020 Jun 23];1-24. Available from: https://www.aljazeera.com/news/2020/03/bangladesh-scientists- 
create-3-kit-detect-covid-19-200323035631025.html

45. Carthaus A. The immune system's fight against the coronavirus [Internet]. [cited 2020 Jun 23]. Available from: https://www.dw.com/en/the-immune-systems-fight-againstthe-coronavirus/a-53048894

46. Mandavilli A, Thomas K. Will a Coronavirus Antibody Test Allow Us to Go Back to School or Work? [Internet]. The New York Times. 2020 [cited 2020 Jun 24].

Available from: https://www.nytimes.com/2020/04/10/health/coronavirus-antibodytest.html

47. Elabscience. Rapid COVID-19 Testing Kit | Coronavirus Test Kits [Internet]. Elabscience. 2020 [cited 2020 Jun 24]. Available from:

https://www.elabscience.com/p-covid_19_igg_igm_rapid_test-375335.html

48. Device VM. Bangladesh approves low-cost test kit to detect Covid-19. Verdict Medical Device [Internet]. 2020 [cited 2020 Jun 24]; Available from: https://www.medicaldevice-network.com/news/bangladesh-low-cost-covid-19-test/

49. Rabbi AR, Tithila KK. BSMMU rejects Gonoshasthaya's Covid-19 test kit. Dhaka Tribune [Internet]. 2020 Jun 17 [cited 2020 Jun 24]; Available from:

https://www.dhakatribune.com/bangladesh/2020/06/17/bsmmu-rejects-gonoshasthayakendra-s-covid-19-test-kit

50. Online Report S. Dr Zafrullah receiving plasma therapy, doing well. The Daily Star [Internet]. 2020 [cited 2020 Jun 24]; Available from:

https://www.thedailystar.net/coronavirus-update-news-dr-zafrullah-receiving-plasmatherapy-doing-well-1905817

51. Correspondent S. Gonoshasthaya Rapid Test Kit: BSMMU speaks at last, spurns it. The Daily Star [Internet]. 2020 Jun 18 [cited 2020 Jun 24]; Available from: https://www.thedailystar.net/frontpage/news/gonoshasthaya-rapid-test-kit-bsmmuspeaks-last-spurns-it-1916337

52. Abdullah M. Coronavirus: Gonoshasthaya Kendra hands over test kits to BSMMU, CDC for final approval. Dhaka Tribune [Internet]. 2020 Apr 25 [cited 2020 Jun 24]; Available from:

https://www.dhakatribune.com/health/coronavirus/2020/04/25/gonoshasthaya-kendrahands-over-coronavirus-testing-kits-to-government

53. Desk T. BSMMU panel to test Gonoshasthaya kits | Dhaka Tribune. Dhaka Tribune [Internet]. 2020 May 2 [cited 2020 Jun 24]; Available from: https://www.dhakatribune.com/health/coronavirus/2020/05/02/bsmmu-panel-to-testgonoshasthaya-kits

54. AA News Desk. Gonoshasthaya submits 200 samples of Corona testing kits to BSMMU. The Asian Age [Internet]. 2020 May 14 [cited 2020 Jun 24]; Available from: https://dailyasianage.com/news/229394/gonoshasthaya-submits-200-samples-ofcorona-testing-kits-to-bsmmu

55. Wu YC, Chen CS, Chan YJ. The outbreak of COVID-19: An overview [Internet]. Vol. 83, Journal of the Chinese Medical Association. Wolters Kluwer Health; 2020 [cited $2020 \mathrm{Jul}$ 10]. p. 217-20. Available from: /pmc/articles/PMC7153464/?report=abstract

56. Hartiadi LY, Crystalia A. Which drugs are effective for COVID-19? 2020 May 5 [cited 2020 Jun 24]; Available from: https://www.thejakartapost.com/academia/2020/05/05/which-drugs-are-effective-forcovid-19.html

57. Zhou M, Zhang X, Qu J. Coronavirus disease 2019 (COVID-19): a clinical update [Internet]. Vol. 14, Frontiers of Medicine. 2020 [cited 2020 Jul 10]. p. 126-35. Available from: https://link.springer.com/content/pdf/10.1007/s11684-020-0767-8.pdf

58. Bangladeshi doctors claim to have found effective drugs to treat COVID-19. The 
Business Standard [Internet]. 2020 May 17 [cited 2020 Jun 29]; Available from: https://tbsnews.net/coronavirus-chronicle/covid-19-bangladesh/bangladeshi-doctorsclaim-have-found-effective-drugs-treat

59. Sujan MA; Use of Ivermectin: Hope held out, caution called for. The Daily Star [Internet]. 2020 Jun 14 [cited 2020 Jun 29]; Available from:

https://www.thedailystar.net/frontpage/news/use-ivermectin-hope-held-out-cautioncalled-1914041

60. Chen L, Xiong J, Bao L, Shi Y. Convalescent plasma as a potential therapy for COVID-19 [Internet]. Vol. 20, The Lancet Infectious Diseases. Lancet Publishing Group; 2020 [cited 2020 Jun 24]. p. 398-400. Available from:

http://www.thelancet.com/article/S1473309920301419/fulltext

61. MDLinx. Ivermectin stops SARS-CoV-2 virus growing in cell culture. ScienceDaily Top Health [Internet]. 2020 Apr 6 [cited 2020 Jun 24]; Available from: https://www.mdlinx.com/news/ivermectin-stops-sars-cov-2-virus-growing-in-cellculture/6ATltJaCRUdaDFL2VjKFmm

62. GEN. Anti-Parasitic Drug Halts Coronavirus Replication in Lab-Grown Cells within 48 Hours [Internet]. Genetic Engineering \& Biotechnology News. 2020 [cited 2020 Jun 24]. Available from: https://www.genengnews.com/virology/coronavirus/antiparasitic-drug-halts-coronavirus-replication-in-lab-grown-cells-within-48-hours/

63. Caly L, Druce JD, Catton MG, Jans DA, Wagstaff KM. The FDA-approved drug ivermectin inhibits the replication of SARS-CoV-2 in vitro. Antiviral Res. 2020 Jun $1 ; 178: 104787$.

64. The Pharma Letter. 'Ivermectin can kill COVID-19 within 48 hours', Monash University study finds. [Internet]. 2020 [cited 2020 Jun 24]. Available from: https://www.thepharmaletter.com/article/ivermectin-can-kill-covid-19-within-48hours-monash-university-study-finds

65. Crump A, Omura S. Ivermectin, "Wonder drug” from Japan: The human use perspective [Internet]. Vol. 87, Proceedings of the Japan Academy Series B: Physical and Biological Sciences. The Japan Academy; 2011 [cited 2020 Jun 24]. p. 13-28.

Available from: /pmc/articles/PMC3043740/?report=abstract

66. Delta Pharma Ltd. Delta Pharma Products,Scabo-6 [Internet]. [cited 2020 Jun 24]. Available from:

http://www.deltapharmabd.com/brandproducts/Our_All_Products?page=7\#

67. Ivermectin Oral: Uses, Side Effects, Interactions, Pictures, Warnings \& Dosing [Internet]. WebMD[Online]. [cited 2020 Jun 24]. Available from: available:https://www.webmd.com/drugs/2/drug-1122/ivermectin-oral/details

68. Ivermectin (Oral) | Indications, Pharmacology, Dosage, Side Effects \& other Generic info with Available Brand names in Bangladesh | Medex [Internet]. MedEx. [cited 2020 Jun 24]. Available from: https://medex.com.bd/generics/644/ivermectinoral/brand -names

69. Anderson JL, Muhlestein JB. Antibiotic trials for coronary heart disease. Texas Hear Inst J [Internet]. 2004 [cited 2020 Jul 22];31(1):33-8. Available from: http://www.ncbi.nlm.nih.gov/pubmed/15061624

70. Ivermectin (Oral) $\mid$ List of Available Brand Names with Prices in Bangladesh [Internet]. MedEx. [cited 2020 Jun 24]. Available from: https://medex.com.bd/generics/644/ivermectin-oral/brand-names

71. Syal K. COVID-19: Herd Immunity and Convalescent Plasma Transfer Therapy [Internet]. Journal of Medical Virology. John Wiley and Sons Inc.; 2020 [cited 2020 Jul 9]. Available from: http://doi.wiley.com/10.1002/jmv.25870

72. Iyer M, Jayaramayya K, Subramaniam MD, Lee S Bin, Dayem AA, Cho SG, et al. 
COVID-19: An update on diagnostic and therapeutic approaches. BMB Rep [Internet]. 2020 [cited 2020 Jun 24];53(4):191-205. Available from:

/pmc/articles/PMC7196187/?report=abstract

73. Wang L, Wang Y, Ye D, Liu Q. Review of the 2019 novel coronavirus (SARS-CoV-2) based on current evidence. Int J Antimicrob Agents. 2020 Jun 1;55(6):105948.

74. Lai ST. Treatment of severe acute respiratory syndrome. Vol. 24, European Journal of Clinical Microbiology and Infectious Diseases. 2005. p. 583-91.

75. Soo YOY, Cheng Y, Wong R, Hui DS, Lee CK, Tsang KKS, et al. Retrospective comparison of convalescent plasma with continuing high-dose methylprednisolone treatment in SARS patients. Clin Microbiol Infect [Internet]. 2004 Jul 1 [cited 2020 Jun 29];10(7):676-8. Available from: https://linkinghub.elsevier.com/retrieve/pii/S1198743X14629025

76. Cheng Y, Wong R, Soo YOY, Wong WS, Lee CK, Ng MHL, et al. Use of convalescent plasma therapy in SARS patients in Hong Kong. Eur J Clin Microbiol Infect Dis. 2005 Jan;24(1):44-6.

77. Ko JH, Seok H, Cho SY, Ha YE, Baek JY, Kim SH, et al. Challenges of convalescent plasma infusion therapy in Middle East respiratory coronavirus infection: A single centre experience. Antivir Ther [Internet]. 2018 [cited 2020 Jun 29];23(7):617-22. Available from: http://www.intmedpress.com/index.cfm?pid=12

78. Lee P, Microbiology PH-J of, Infection I and, 2020 undefined. Emerging threats from zoonotic coronaviruses-from SARS and MERS to 2019-nCoV. Elsevier [Internet]. [cited 2020 Jun 24]; Available from: https://www.sciencedirect.com/science/article/pii/S1684118220300116/pdf?md5=682e ac74614c6814574721240cbafeea\&pid=1-s2.0-S1684118220300116-main.pdf

79. Cao WC, Liu W, Zhang PH, Zhang F, Richardus JH. Disappearance of antibodies to SARS-associated coronavirus after recovery [Internet]. Vol. 357, New England Journal of Medicine. 2007 [cited 2020 Jun 29]. p. 1162-3. Available from:

http://authors.nejm.org

80. Arabi YM, Hajeer AH, Luke T, Raviprakash K, Balkhy H, Johani S, et al. Feasibility of using convalescent plasma immunotherapy for MERS-CoV infection, Saudi Arabia. Emerg Infect Dis [Internet]. 2016 [cited 2020 Jun 29];22(9):1554-61. Available from: https://www.ncbi.nlm.nih.gov/pmc/articles/PMC4994343/

81. Bobati S, research KN-J of clinical and diagnostic, 2017 undefined. Therapeutic plasma exchange-an emerging treatment modality in patients with neurologic and nonneurologic diseases. ncbi.nlm.nih.gov [Internet]. [cited 2020 Jun 24]; Available from: https://www.ncbi.nlm.nih.gov/pmc/articles/PMC5620780/

82. Ye M, Fu D, Ren Y, Wang F, Wang D, Zhang F, et al. Treatment with convalescent plasma for COVID-19 patients in Wuhan, China. J Med Virol [Internet]. 2020 Jun 29 [cited $2020 \mathrm{Jul}$ 9];jmv.25882. Available from: https://onlinelibrary.wiley.com/doi/abs/10.1002/jmv.25882

83. Duan K, Liu B, Li C, Zhang H, Yu T, Qu J, et al. Effectiveness of convalescent plasma therapy in severe COVID-19 patients. Proc Natl Acad Sci U S A [Internet]. 2020 Apr 28 [cited 2020 Jun 24];117(17):9490-6. Available from: https://www.pnas.org/content/117/17/9490

84. Cao Y chen, Deng Q xin, Dai S xue. Remdesivir for severe acute respiratory syndrome coronavirus 2 causing COVID-19: An evaluation of the evidence. Vol. 35, Travel Medicine and Infectious Disease. Elsevier USA; 2020. p. 101647.

85. Adebayo T. Covid-19 treatment: Bangladesh produces world... - Daily Times Nigeria [Internet]. The daily times. 2020 [cited $2020 \mathrm{Jul}$ 8]. Available from: available:https://dailytimes.ng/covid-19-treatment-bangladesh-produces-worlds-first- 
generic-remdesivir/

86. Report T. Govt hospitals to get Beximco Remdesivir for free. The Business Standard [Internet]. 2020 May 21 [cited 2020 Jun 29]; Available from:

https://tbsnews.net/bangladesh/health/remdesivir-will-be-free-covid-19-patients-govthospitals- 84058

87. Beigel JH, Tomashek KM, Dodd LE, Mehta AK, Zingman BS, Kalil AC, et al. Remdesivir for the Treatment of Covid-19 - Preliminary Report. N Engl J Med [Internet]. 2020 May 22 [cited 2020 Jul 8]; Available from: https://www.nejm.org/doi/full/10.1056/NEJMoa2007764

88. Grein J, Ohmagari N, Shin D, Diaz G, Asperges E, Castagna A, et al. Compassionate use of remdesivir for patients with severe Covid-19. N Engl J Med [Internet]. 2020 Jun 11 [cited $2020 \mathrm{Jul}$ 9];382(24):2327-36. Available from: http://www.nejm.org/doi/10.1056/NEJMoa2007016 